\title{
REGIONAL EFFECTS OF TRANSPORT CORRIDOR NO. 10 IN VOJVODINA
}

\section{A VAJDASÁG 10-ES KÖZLEKEDÉSI FOLYOSÓJÁNAK REGIONÁLIS HATÁSAI}

Áron Kovács, $\mathrm{PhD}$ student, scientific research assistent

Pécsi Tudományegyetem, Közgazdasági Kar, Regionális Politika és Gazdaságtan Doktori Iskola

Address: $\quad 24414$ Hajdújárás, Kosztolányi Dezső 13.

Phone: $\quad+36706585235$

E-mail:_aronkovac@gmail.com 


\title{
A VAJDASÁG 10-ES KÖZLEKEDÉSI FOLYOSÓJÁNAK REGIONÁLIS HATÁSAI
}

\section{REGIONAL EFFECTS OF TRANSPORT CORRIDOR NO. 10 IN VOJVODINA}

Keywords: Corridor No. 10., motorway, Vojvodina, regional effect, access.

\begin{abstract}
:
The construction of what today is transport corridor No.10 in Serbia was begun in the 1990s but because of the civil war the fully completed Vojvodina section was declared open for the general public in 2012. The present study examines the main cost indicators of the motorway, surveys the social expectations of the European Union and Serbia, introduces the system of conditions necessary for favorable regional effects, and finally, the study outlines the effect the motorway has on the settlements of Vojvodina - the access of the seat of the territory and the amount of FDI.
\end{abstract}

Kulcsszavak: 10-es korridor, autópálya, Vajdaság (Vojvodina), regionális hatás, elérhetőség.

\section{Kivonat:}

A mai 10-es közlekedési folyosót Szerbia már a '90-es években elkezdte kiépíteni, de a polgárháborúk miatt a teljes vajdasági szakaszt 2012-ben adták át a forgalomnak. A tanulmány először elemzi az autópálya építési föbb költségmutatóit, feltérképezi a 10-es folyosóhoz kötődő Európai Unió és Szerbia társadalmi elvárásait, bemutatja a kedvező regionális hatásokhoz szükséges feltételrendszert és végül vázolja az autópálya Vajdaság településeire gyakorolt hatásait - tartomány székhelyének elérhetőségében, külföldi befektetések nagyságában.

\section{BEVEZETÉS}

A közlekedés egyik olyan ágazat, amely minden gazdasági folyamattal kapcsolatba hozható, közvetetten és közvetlenül is befolyásolja a régió és az ország gazdaságát illetve társadalmi folyamatait. A közlekedés fejlődésének térformáló hatásai a történelemből már ismertek; egyes régiók kiemelkedtek majd a közlekedés irányok megváltozása következtében visszafejlődtek. A regionális tudomány területén is számos irányzat használta fel a közlekedést különféle gazdasági folyamatok magyarázatához. Gazdasági elméletek is épültek a közlekedésre, illetve a szállítási költségek változására alapozottan. Mindezek arra késztettek, hogy tanulmányom témájaként a Vajdaság régiói fő közlekedési útvonala 10-es autópályát és annak regionális hatását feltérképezzem. Emellett a dolgozat célja, hogy a közlekedés hatásait makro- (állami) és mikro (kisvállalati és egyéni) szinten bemutassa, illetve összpontosítva arra a kérdésre, hogy a közlekedés helyzete a régiót, az ott élők mindennapjait milyen módon befolyásolja, milyen gazdasági elemek társulnak a közlekedési 
módozatok fejlődéséhez, mik azok az elemek, amelyek gátolják és segítik egyes közlekedési alágazatok és az egész régió fejlődését.

A dolgozatban bemutatom a Vajdaság 10-es (PEN) folyosójának a tervezését, az autópályáihoz kötődő társadalmi elvárásokat, a térbeli hatásuk kifejtéséhez szükséges feltételrendszer megteremtését és a jelenlegi hatásokat.

\section{A 10-es korridor szerbiai szakaszának építése}

A mai 10-es közlekedési folyosót Szerbia már a '90-es években elkezdte kiépíteni, majd az ország átalakulása, pontosabban a balkáni háborúk miatt az építkezés megszakadt, folytatására csak 2004-ben került sor. A Horgos-Újvidék szakaszon ,fél autópálya”, Újvidék-Belgrád között négysávos autópálya fizetőkapukkal együtt már megépült.

A munkálatok folytatására az első pályázatkiírás már 2007-ben megtörtént. A szerb állam által meghirdetett 10-es autópálya megépítésére számos külföldi vállalat jelentkezett, mint a Bouygues, a Vinchi, a GMP, az Alpina és a Strabag. A pályázatot az osztrák érdekeltségü „Alpina-Por” vállalategyüttes nyerte el. A megállapodást 2007. március 30-án írták alá következő feladatok felvállalásával:

- a Horgos-Újvidék szakasz autóút baloldali forgalmi sávjának kiépítése (106km),

- az Újvidék-Belgrád autópálya felújítása (68 km),

- a Belgrád-Požega autópálya tervezése és kivitelezése (148km).

Ezen felül a megállapodás azt is tartalmazta, hogy a szerb állam nem fektet be semmilyen pénzeszközt és nem is visel semmiféle kockázatot a munkálatok kivitelezéséért. Ennek fejében az állam 25 évre átruházza az „Alpina-Por“ vállalategyüttesre az autópálya használati díjának beszedési jogát. Ez a megállapodás a B.O.T koncessziós modellnek ${ }^{6}$ felel meg. A felválallt munka az összértéke körülberül 1,5 milliárd euró volt. A kivitelezés határidejét 5 évben állapították meg és az építkezéseknek 2009 januárjától kellett volna megindulnia.

\footnotetext{
5 „fél autópálya” - A leendő autópálya elsőként megépült egyik pályája (a „fél autópálya”) autóútként használható. Ezeknek az autóutak vonalvezetése, méretezése, geometriája valójában autópálya-jellegü, korlátjuk "csak" abból fakad, hogy a szembejövő forgalom karnyújtásnyira van, és a majdani leálló sáv is a folyamatos forgalomba be van vonva - ezért az ilyen autóutak kitáblázása ideiglenes jellegű, a másik fél autópálya elkészültéig tart.

${ }^{6}$ B.O.T. modell (build-operate-transfer), építi-felügyeli-átadja.
} 
Rövid idő alatt 2008. junius 17.-én megalakult a Nemzeti Infrastrukturális Tanács, mely elvetette a további együttmüködést az „Alpina-Por“ vállalat együttessel és továbbiakban a koncessziós szerződést semmisnek tekintették. Az „Alpina-Por“ nemzetközi bírósághoz fordult kártérítésért.

A koncessziós szerződés felrúgásának „köszönhetően” az ország nem írhatott ki újabb nemzetközi pályázatott a 10-es folyosó kiépítésére, hanem hazai befektető vállalatokat

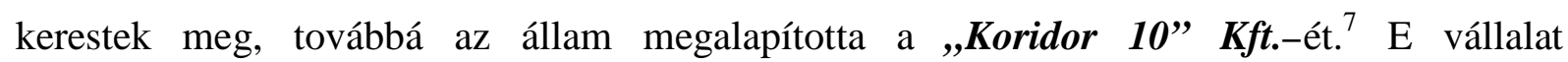
megalapításának célja az volt, hogy a Szerbiában a megkezdett közlekedés-infrastruktúra kiépítése folytatódni tudjon. Időközben a „Koridor 10” Kft alapító okiratát megváltoztatták és átnevezték „Koridor Srbija”-ra. ${ }^{8}$ Ezek után a vállalat elsősorban közlekedési infrastrukturális befektetési feladatokat látott el. Ezen felül szakmai feladatokat teljesített, mégpedig minden terv- és projektdokumentációt elkészített, amely a 10-es folyosó szerbiai szakaszához tartozott, megtervezte az autópályák építését, végrehajtotta a földvásárlást illetve a kisajátítást. A „Koridor 10” a következő projektek megvalósítására kapott felhatalmazást (1. ábra):

- E75 út Szabadka-Újvidék szakasz (115 km)

- E75 út Grabovica-Presevo szakasz $(96,1 \mathrm{~km})$

- E80 út Nis-Dimitrograd szakasz $(83,4 \mathrm{~km})$

- / belgrádi kerülőút

\footnotetext{
${ }^{7}$ A ,Szerbia Utak” közvállalattól teljesen különálló vállalkozás, feladata a 10-es autópálya megépítésének elősegítése.

${ }^{8}$ A névváltoztatás 2011.január 21. óta érvényes, továbbra is kft-ként müködik. A társaság a következő honlapon érhető el: http://www.koridor10.rs/.
} 


\section{1. Ábra. Szerbián áthaladó 10-es autópálya építési szakaszai}

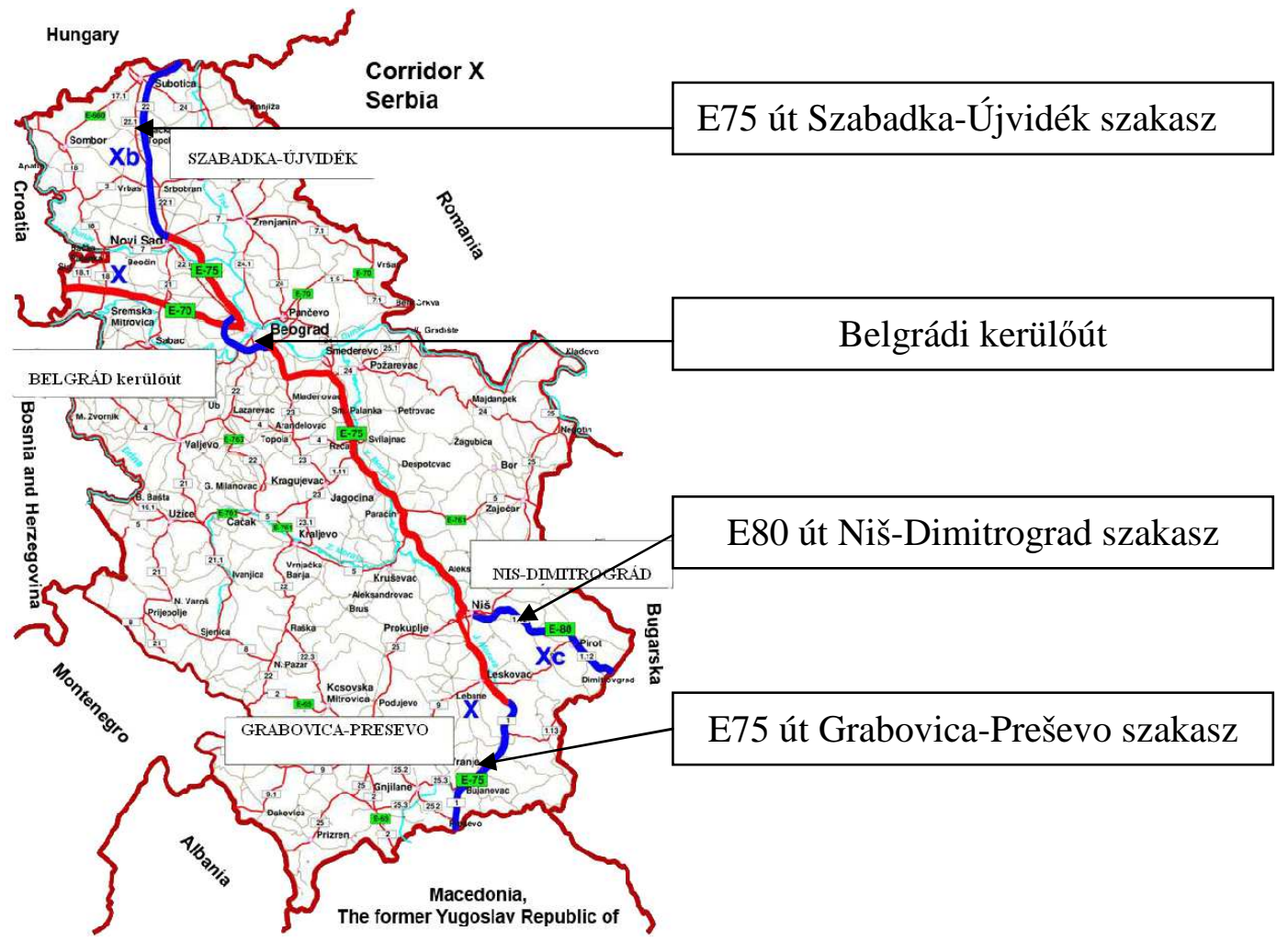

Forrás: Infrastrukturális Minisztérium „Koridor 10” vállalat esettanulmánya, 2008. szeptember.

A „Koridor 10” kft. újból kiírta a pályázatot a 10-es folyosó szerbiai szakaszának megépítésére. A szerb építkezési vállalatok konzorciumba tömörültek és megalapították a „Nibens” csoportot. ${ }^{9}$ A pályázat feltételeinek legmegfelelőbbnek a 'Nibens”csoportot találták, mert a legalacsonyabb árat kínálta (9,97 milliárd dinárt) és vállalta, hogy ezt a legrövidebb időn belül (22 hónap alatt) megépíti.

A koncessziós szerződés felrúgása és a „Koridor 10” vállalat megalakítása után elindulhatott Szerbia legnagyobb közlekedési beruházása. Az egész útszakasz 1,63 milliárd euró összegü költségeknek egy részét saját büdzséjéből finanszírozza az állam, a hiányzó eszközöket pedig külföldi pénzintézetek hiteléből pótolja. A finanszírozási forrás összetételét az 1-4. táblázat részletezi.

\footnotetext{
${ }^{9}$ A Nibens csoportba következő vállalatok tartoztak: Belgrádi, Niši, Kragujevaci, Vranjei Közutak vállalatok, továbbá „Partizanski Putevi” építkezési vállalat, „Signalizacija Putevi” vállalat, FAM kenőanyag gyár, „Nibens Kameni” vállalat, „Budućnost” építkezési vállalat, „Straževica” vállalat, ZGOP vállalat és „Vojvodina-Bačka” vállalat.
} 


\section{Táblázat. A 10-es korridor szerbiai szakasz kiépítésének forrásterve}

\begin{tabular}{|l|r|}
\hline Világbank - hitel & 380 millió $€$ \\
\hline Európai Beruházási Bank - hitel & 600 millió $€$ \\
\hline Európai Újjáépítési és Fejlesztési Bank - hitel & 150 millió $€$ \\
\hline Görögország - adomány & 100 millió $€$ \\
\hline Szerbia - büdzsé & 1.63 milliárd $€$ \\
\hline
\end{tabular}

Forrás: saját szerkesztés a Blic napilap 2009.05.11.-ei száma alapján

Ahhoz hogy a tervezett időben elkészüljenek az útszakaszok a kivitelezéshez 20.000 munkásra és a kísérő projektekhez közel 100.000 emberre van szükség.

\section{Táblázat. A 10-es korridor szerbiai szakasz kiépítésének költségterve}

\begin{tabular}{|l|r|}
\hline Horgos-Újvidék & 132 millió $€$ \\
\hline Leskovac-Preševo & 604.3 millió $€$ \\
\hline Niš-Dimitrograd & 647.9 millió $€$ \\
\hline Belgrádi leágazás & 221 millió $€$ \\
\hline Batajnicai leágazás & 115 millió $€$ \\
\hline Összesen & $\mathbf{1 . 8}$ milliárd $€$ \\
\hline
\end{tabular}

Forrás: Infrastrukturális Minisztérium „Koridor 10” vállalat esettanulmánya, 2008. szeptember

Az Infrastrukturális Minisztérium Szerbia részére 2011-2032-ig az autóút szolgáltatásaiból 4,3 millió $€$ nyereséget tervez. A befektetés megtérülési ideje 10 év. Nyereség 2014-tól várható, amikor is a munkálatok befejeződnek és a bevételek megduplázódnak. Nemcsak regionális és nemzetközi szempontból van összekötő szerepe a térségben az észak-dél irányú fejlődési tengely kiépítésének, hanem anyagi forrása is lehet üzemelésekor az állam költségvetésének. 
3. Táblázat. A 2009-2018 között tervezett költség/bevétel tételek összehasonlítása (Mil.€)

\begin{tabular}{|l|r|r|r|r|r|r|r|r|r|r|}
\hline Év & \multicolumn{1}{|l|}{2009} & \multicolumn{1}{|l|}{2010} & \multicolumn{1}{|l|}{2011} & \multicolumn{1}{|c|}{2012} & 2013 & 2014 & 2015 & 2016 & 2017 & 2018 \\
\hline Építési költ. & 272,8 & 272,8 & 272,8 & 272,8 & 272,8 & 136,4 & 136,4 & 136,4 & 136,4 & 136,4 \\
\hline $\begin{array}{l}\text { Karbantartási } \\
\text { költ. }\end{array}$ & 12,5 & 12,5 & 12,5 & 12,5 & 12,5 & 12,5 & 12,5 & 12,5 & 12,5 & 12,5 \\
\hline Bevétel & 150,8 & 150,8 & 150,8 & 150,8 & 150,8 & 301,7 & 301,7 & 301,7 & 301,7 & 301,7 \\
\hline Nyereség & $-134,5$ & $-134,5$ & $-134,5$ & $-134,5$ & $-134,5$ & 152,5 & 152,8 & 152,8 & 152,8 & 152,8 \\
\hline
\end{tabular}

Forrás: saját szerkesztés a Blic napilap 2009.05.11.-ei száma alapján, letölthető: http://www.blic.rs/Vesti/Tema-

Dana/91876/Koridor-10-posao-za-200000-ljudi

A tervek szerint 2018 után az éves építési költségek megszünnek és csak a karbantartási munkálatok költségeivel, éves 12,5 millió euró összeggel kell számolni, míg az éves úthasználati díj 301,7 millió euró bevételt biztosít. Így a nyereség évente 289,2 millió euró. Ha az összbevételt nézzük 2009-2032 között, akkor 4338 millió euróra számít az ország, a tervezett összkiadások 1630 millió euró, a nyereségesség közel háromszoros, ezért a megvalósítása kétségkívül előnyös.

\section{Táblázat. A 2018 és 2032 közötti időszakban becsült közvetlen bevételek a korridor 10-es üzemeltetésekor}

\begin{tabular}{|l|l|}
\hline Úthasználati díj és belépési illeték & 200-300 millió € \\
\hline Kiegészítő szolgáltatások (töltőállomás, motel, autó szerviz, posta, stb.) & $5-15$ millió $€$ \\
\hline Benzin eladás & 2,8 milliárd €/év \\
\hline
\end{tabular}

Forrás: Infrastrukturális Minisztérium „Koridor 10” vállalat esettanulmánya, 2008. szeptember

Az infrastrukturális miniszter ígérete ellenére sem fejeződnek be a munkálatok 2014-re. A legoptimistább becslés szerint is ez a dátum 2016-ra kitolódik, mert még az elkezdett útszakaszok munkálatai sem fejeződnek be 2013-ra. Csupán 147 kilométer útpálya befejezése lehetséges 2014-re.

A problémák a tervezéssel kezdődtek a tervek megrendelése is késett, mert ahhoz nem volt biztosítva az anyagi forrás. Azoknak az útszakaszoknak a megvalósítását, amelyekhez a tervdokumentáció elkészült, annak megvalósítását nem kezelték prioritásként. Az ország 2008-ban 150 millió eurót használt fel a tervek elkészítésére és a szükséges területek kisajátítására. Mivel a privatizáció lassú ütemben folyt, ezért az ország kedvező (3-4\% 
kamattal terhelt) hitelfelvételre kényszerült. A pénzt az Észak-Dél szakasz és Belgád-Adriai tenger útszakasz tervezésére költötte. A projektek és a kisajátításokkal járó munkák nem fejeződtek be, így a határidők tovább kitolódnak.

A munkát nehezíti az is, hogy a kivitelezó ${ }^{10}$ drága (15-17\%-os kamattal terhelt) banki hitelekhez felvételére kényszerültek, mert a pályázatokon elnyert munkát másképpen nem tudták befejezni, annak ellenére, hogy a válság miatt a munkaerő ára alacsony maradt.

Az építkezések (az ország integrációs folyamataihoz hasonlóan) döcögősen, késésekkel haladnak. A 10-es autópálya végső soron egy komplex infrastrukturális létesítmény, amelynek a tervezése, kisajátítása, pályáztatása és a kivitelezése összetett, egymásra épülő munkát igényel, de Szerbia esetében ezek a folyamatok - részben összehangoltság hiánya miatt - késnek, csúsznak, halasztódnak. A gazdasági válság miatt az állami költségvetés hiányokkal küzd, ${ }^{11}$ a privatizáció lelassult, a nagy állami intézmények eladhatatlanokká váltak. Az ország az úthasználati díjának beszedéséből évente 289,2 millió euróra számít, de az építkezések késése miatt 150 millió veszteségre is fel kell készülni, ezen túlmenően az „Alpina-Por”-ral felrúgott koncessziós szerződés 71 millió euró költségei nehezebbé teszik a zökkenőmentes kivitelezést. Ebből adódóan az Infrastrukturális Minisztérium által készített esettanulmány alapján a költség és bevétel adatok már nem állják meg a helyüket. Az egész szerbiai autópálya beruházás az ígéretekre és a határidők sorozatos mulasztásaira épül.

\section{A 10-es korridor társadalmi elvárásai az Európai Unió és Szerbia szemszögéből}

Közös egységes európai közlekedés igénye először az 1957-ben a Római Szerződésben jelent meg, amelyben szükséges infrastrukturális háttér megteremtése csak még mint közös cél került szóba.

Az első európai autópálya program kidolgozására 1962-ben került sor, finanszírozása megmaradt nemzeti szinten (ennek legfőbb okai az olajválság és a recesszió voltak). A '80-as évek végére azonban a Közös-Európai komplex Közlekedési Infrastruktúra programnak köszönhetően a közös közlekedési törekvések felerősödtek. Jelentős mozzanat volt még 1989-ben a Strasbourgi-csúcs, ahol elfogadták a Transzeurópai Hálózat (TEN) alapelveit. A Maastrichti Szerződés külön figyelmet szentelt a TEN-T fejlesztésének kérdéseire.

A '90-es években a közös és egységes közlekedési hálózatban való gondolkodás az Európai Unió határán kívülre, az ún. harmadik országokra is kiterjedt. Az 1994-ben Krétán

\footnotetext{
${ }^{10}$ Elsősorban a Nibens csoport nyúlt hitelhez.

${ }^{11}$ 2012-es költségvetési hiány 140 milliárd dinár ₹1,4 milliárd euró, eladósodottság szintje GDP 45\%-a.
} 
megtartott II. Páneurópai Közlekedési Értekezleten az akkori Jugoszlávia közlekedési hálózatát a nemrég véget ért polgárháború miatt még nem tervezték bekapcsolni az európai vérkeringésbe. A három évvel későbbi 1997-ben Helsinkiben megtartott Közlekedési Értekezleten már módosult a krétai folyosók terve és a balkáni országok bekerültek hálózatépítésbe $a X$. és Vc. korridorok tervezésével.

Krétai folyosók (módosított) útvonalai, illetve Helsinki 10-es folyosó:

Salzburg-Graz-Ljubljana-Zágráb-Belgrád-Budapest-Nis-Szkopje-Szófia-Veles-

\section{Szaloniki}

A balkáni országok páneurópai közös közlekedési hálózatba való befogadásának célja az volt, hogy az elszigeteltséget és a kirekesztettséget a Közösség ellensúlyozza, illetve a nyugati és a keleti országok között utat nyissanak.

A fejlesztésekhez szükséges pénzeszközöket a Maastrichti Szerződésen belül a Kohéziós alap biztosította 1993-1999-ig 15 milliárd ECU ${ }^{12}$ összegben és további 15 milliárd euró kizárólag infrastrukturális fejlesztésekre használhatták fel. Az 1992-ben elfogadott Európai Növekedési Kezdeményezés a tagállamokat újabb pénzforráshoz jutatta, amelyeket elsősorban gazdasági és hálózatépítésre fordíthattak. A pénzügyi támogatás nagysága tanulmányok készítésénél legfeljebb 50\%-os és beruházásnál 10\%-os ${ }^{13}$ volt.

$\mathrm{Az}$ ezredforduló előtt a 10-es folyosó közút tekintetében a Vajdaságban ,fél autópályaként” már működött, ezért a lakosság részéről nagymértékű igény a teljes kiépítése nem tanúsított. A tranzit forgalom jelentős része már az Európai Unió schengeni befogadó kapujaként használta a Horgos-Röszke határátkelőt. A Nyugat-Európában dolgozó török vendégmunkások is felfedezték maguknak a „gyors és kényelmes”14 közlekedési folyosót. Szerbiában az autópálya két sávosról négy sávosra való bővítését kiemelt fontossággal kezelték. Az autópálya nem is igazán a helyi lakosság kényelmét, a települések, városok gyors elérhetőségét biztosítja a vidéki térségekböl, hanem inkább szimbolikus jelentőséggel bír.

\footnotetext{
${ }^{12}$ ECU - Európai Elszámolási Egység (European Currency Unit) Az ECU az úgynevezett számlapénzként létező kosárvaluta, aminek értékének meghatározásakor a tagállamok valutáit eltérő súllyal veszik számításba. Az ECU készpénz formájában nem létezik, de sokféle más formában azonban igen. Így például ECU-ben állapítják meg az EU költségvetését, kötvényeket bocsátanak ki ECU-címletekben, segélyeket, kölcsönöket és bankhiteleket nyújtanak egymásnak és harmadik országoknak.

${ }^{13} 2004$ óta a TEN projektekre a támogatást 10\%-ról felemelték 20\%-ra.

${ }^{14}$ A határátkelőnél az ünnepek, szabadságok idején nem ritka a több kilométeres kocsisor és a 3-4 órás várakozási idő.
} 
Kiépülésével az ország bizonyítani próbálja, hogy valóban Európa része és a háborúk okozta bezártsága és a Nyugattal való politikai szembefordulás már a múlté.

\section{A 10-es korridor kedvező regionális hatásaihoz szükséges feltételrendszer bemutatása}

A közlekedési hálózatok fejlesztésének egyértelmű közvetlen hatása, hogy a távolságok időben lerövidülnek. A közvetett hatás, miszerint növeli a gazdasági, társadalmi kohéziót, már nem bizonyított. Szerintem az autópálya gazdasági hatását csak akkor fejti ki, ha az alábbi feltételrendszernek megfelelnek:

- Az autópálya határtól-határig terjed,

- prosperáló gazdasági háttérben müködik,

- használatarányos díjbeszedés valósul meg, és

- multimodális szállítás biztosított.

\subsection{Első feltétel: Határtól-határig terjedő autópálya}

A volt szocialista államok közül Jugoszláviában épült a legtöbb autópálya. Az úthálózat kialakítása szerepet játszott a nagy területű szövetségi államon belüli közös piac elérésében is. „A közlekedésben domináló közúthálózat gerince észak-dél irányúra változott, mivel az ország területe kelet-nyugat irányba lényegesen „lerövidült”, s a korábbi Jugoszlávia regionális központjaival való összeköttetések jelentősége leértékelődött, háttérbe szorítva az ilyen irányú fejlesztéseket”. (Nagy 2007, 44.)

Az észak-déli kapcsolat is egyre erősödött a szocializmus gyengülésével, így már a 80-as években megépítették a Belgrád-Újvidék-Topolya pályát. Ez az autópálya azonban csak félpályás volt, noha sehol sem voltak szintbeli kereszteződések. A délszláv polgárháború első éveiben folytatódott a beruházás, így sikerült még átadni a Topolya-Szabadka-Horgos részt, de a magyar-szerb határig már nem jutottak el, pedig a magyar oldalon már elkészült a Hegyeshalom-Győr-Budapest-Kecskemét-Szeged-Röszke határtól határig terjedő szakasz.

A korridor 10-es autópálya vajdasági szakaszát 2007-ben kezdték el újra kiépíteni, de a munkálatok csak 2011 végére fejeződtek be. A határtól határig szakaszt teljes mértékben kielégíti, mert a Helsinki 10-es folyosó Vajdaságot összeköti Magyarországgal (Horgosnál) és Horvátországgal (Vatrovcinál). Az autópálya elsősorban a Közel-Kelet és Közép-Európa közötti kapcsolati szerepet tölti be. Németország számára ez az autópálya a török vendégmunkások hazajutását biztosítja. A napi átlagforgalom a M6-oshoz hasonló HorgosÚjvidék 5.794 és Újvidék-Belgrád szakaszon 12.684 jármű. A főváros központúság azonos 
mértékben hat a közlekedés intenzitására mindkét országban. Belgrád, mint főváros megmaradt centrumként és minden szolgáltató, nagybank és nagykereskedelmi vállalat székhelye. Közlekedési, telekommunikációs csomópont és logisztikai és szállítmányozási szempontból is domináns. Minden fontosabb útvonal keresztülhalad rajta. Vajdaság, mint régió továbbra is Belgrád közvetlen irányítása alatt áll és nem tud kellő önállóságot nyerni ahhoz, hogy kiépítse a saját közlekedését, iparát, városhálózatát.

Az elsö feltételt (határtól-határig tartó vonulat) csak a korridor 10-es autópálya elégíti ki, mert teljes mértékben illeszkedik a Helsinki folyosók irányvonalához.

\subsection{Második feltétel: Prosperáló gazdasági háttér}

A Vajdaság egykor Szerbia „motorja” volt és Szlovénia gazdaságát is megközelítette, felülmúlva Horvát, Szerb, Montenegró és Macedón tagállamokét. Ma már ettől a teljesítménytől messze elmarad. A Vajdaságra jellemző, hogy átalakult az agrártermelés, mind többen a szolgáltató iparba menekülnek a hibás agrárpolitika miatt. A falvak már nem kimondottan mezőgazdasági termeléssel foglalkoznak, hanem a nagy városok közelében csendesebb, kertvárosi jelleget öltenek. Ezért erős a napi, heti vagy havi ingázás a munkahely és a lakóhely között. Az adatok szerint Szerbiában a lakosság aktív részének 40 \%-a ingázik. Ezek a folyamatok felerősítik az olyan centrumok jelentőségét (közlekedési, infrastrukturális, közszolgálati szemszögből), mint Újvidék, Szabadka, Zombor, Nagybecskerek.

A Szerb Köztársaság vállalkozásainak 26,6\%-a Vajdaságban van, mégis az egy főre jutó GDP az országos átlag alatt mozog. A tartomány 25,6\%-ban (2010) járult hozzá Szerbia GDP összegéhez, amely kiemelkedően magas, de 4,2\%-kal kevesebb, mint 2005-2009 között. A munkanélküliségi ráta magasabb (20,9\%), az átlagfizetés összege pedig (3,5\%-kal) elmarad az ország átlagától. Ipari teljesítményben a Vajdaság városai közül ipari teljesítményben Újvidék emelkedik ki - a város ipari sűrüség indexe ${ }^{15} 2,5$ pontot éri el-, míg a többi vajdasági város esetében ez a szám a 1,0-2,0 között mozog. (Kovács 2011a, 108.) A 2008-as gazdasági válságnak köszönhetően kiviteli rátája az előző évhez képest 25,2\%-kal csökkent. Az ipari termelés nem mutatott látványos fejlődést 2000 és 2011 között, inkább a hanyatlás jellemzi, melynek okait a szerkezetváltás és a fejlesztési programok hiányában kell keresni.

\footnotetext{
${ }^{15}$ Relatív ipari sürüségi index kiszámításához szükséges a területi és demográfiai adatok (terület nagysága és lakosság száma) regionális viszonyokra levetítve. Amikor az index értéke 1, akkor az ipar elterjedése adott területen teljesen egyenletes, természetesen figyelembe véve a terület nagyságát és fejlettségi szintjét.
} 
Az előbbi elemzés alapján a vizsgált régió a leszakadó területek közé sorolható. A gazdasági mutatóik rosszabbak az adott ország átlagánál, és már csak ezért is az autópályája elsősorban nem a helyi gazdaságot szolgálja, hanem a centrumok elérhetőségét biztosítja.

\subsection{Harmadik feltétel: A használatarányos díjbeszedés}

Szerbia egész területén a kilométer alapú autópálya díjszedési rendszer müködik. Vajdaságban két helyen található fizető kapu, az egyik a Horgos-Újvidék szakaszok között Bácstopolya mellett, a másik Újvidék és Belgrád közötti Feketicsnél (a horgosi nemzetközi határátkelő előtt még a fizetőkapu nem üzemel).

\section{Táblázat. A Vajdaságban érvényes úthasználati díjak a két fizetőkapunál (din.-ben)}

\begin{tabular}{|c|c|c|}
\hline Díjkategóriák & Bácstopolya & Feketics \\
\hline D1 & 240 & 330 \\
\hline D2 & 350 & 500 \\
\hline D3 & 710 & 990 \\
\hline D4 & 1420 & 1980 \\
\hline
\end{tabular}

Forrás: Korridor 10 Kft honlapjáról (http://www.koridor10.rs/) (letöltve: 2012. május 11.)

Az európai országok közül Szerbiában a legolcsóbb az autópálya használat (5. táblázat), mert csupán 3 eurócent/km a használati díj, míg Horvátországban és Olaszországban 5 eurócent $/ \mathrm{km}$, Spanyolországban 8,5 eurócent $/ \mathrm{km}$, Franciaországban 9,5 eurócent $/ \mathrm{km}$. A külföldi gépjárművek 2011-től a belföldiekkel azonos összeget fizetnek.

\subsection{Negyedik feltétel: A multimodális szállítás biztosítása}

„A közúti szállitás arányának csökkentése érdekében, minél több feladatot a vasútra, illetve a belvízi hajózásra célszerü terelni. Ennek leghatékonyabb eszköze a kombinált (multimodális) áruszállitás, ahol az áru konténerben, csereszekrényben, pótkocsiban vagy teljes kamionszerelvényben vasúton teszi meg a szállitási út nagyobbik részét." "16

(EUDESK hírlevél) A régióban a multimodális szállítás lehetőségei tekintetében a vasúti, vízi és légi közlekedést is meg kell vizsgálni.

\footnotetext{
${ }^{16}$ Európai Uniós Hírlevél: A Transz-Európai Közlekedési Hálózat és az országos jelentőségű logisztikai központok.
} 
Tranzithelyzetéből adódóan a Vajdaság (ahol a Duna és a Tisza között húzódik a 10-es autópálya) szükségessé teszi az integrált szállítási és logisztikai központok létrehozását. A tervezett központoknak eleget kell tenniük a konténeres, tranzit ki- és berakodás, belső szállítás feltételeinek, illetve a Huckepack és Ro/Ro szállításnak. A Vajdaságban elsődlegesen Szabadka, Zombor, Újvidék, és Pancsova területére terveznek logisztikai központokat. Ezek nagy részben helyileg egybeesnek a vasúton és a közúton tervezett konténeres terminálok építésével.

A Szerbián áthaladó teherforgalom döntő többsége jelenleg a közutakon áramlik, aminek oka az, hogy a még a Monarchia alatt kiépült vasúti hálózat nagy részét az 1960-as évektől felszámolták, a megmaradt pályákat pedig elhanyagolták. Jó példázza a helyzetet, hogy az egykori fővonal (Nagyvárad-Fiume vasút) részét alkotó Szabadka-Szeged nemzetközi szakaszon csupán 40-50 km/óra sebességgel képesek közlekedni a vonatok. Vajdaság vasútvonalainak nagyobb részén a pályák életkora átlagosan több mint 100 év. Bár egyes vonalak területi eloszlása arányos és szerteágazó, a mai technikai követelményeknek már nem felelnek meg. A Vajdaság vasúthálózat sürüsége $\left(74 \mathrm{~km} / 1000 \mathrm{~km}^{2}\right)$ lényegesen nagyobb, mint Szerbia átlaga $\left(43 / 1000 \mathrm{~km}^{2}\right)$, sőt jó néhány más európai országokhoz képest is sürübb. A feltételek a kereslet oldaláról megfelelnek a multimodális közlekedés fejlesztéséhez, csak az elöregedett infrastruktúra felújítása csúszik. Az európai vasúti hálózat alapján a szerbiai vasút hosszú távú fejlesztéseket tervez, melynek egyik prioritása a nagysebességü fejlesztése, ezek a Belgrád-Újvidék-Szabadka-Budapest és Belgrád-Pancsova vonalon kötnék össze a nagyobb városokat.

A folyami közlekedés fejlettségét a vízi utak hajózhatóságának feltétele (medrek mérete, állapota) és a hajóflotta nagysága mellet, a kikötők száma határozza meg. Vajdaságban a 10es autópálya két folyó (a Duna és a Tisza) között halad, ezért a feltételek adottak a folyami hajózás és a közúti forgalom összekötésére, illetve egymás kiegészítésére. A Duna itteni szakaszán a mederviszonyok lehetővé teszik a legnagyobb (1500 tonnás) hajókkal való közlekedést. A Tisza duzzasztója javította a vízmennyiségét, de így is csak a közepes hajókkal járható. A 7-es PEN folyosó (Duna) vajdasági szakasza nincs kellőképpen kihasználva, mert a régió által generált áruforgalomnak csak a 8\%-a halad rajta keresztül (Kovács 2011b. 5.), pedig a Vajdaságban hajózásra 1398 km folyó és csatorna áll rendelkezésre. A tartományban 124 hajó üzemel, melyek az elmúlt időben évente átlagosan 15,5 millió tonna/év árut szállítottak. Jelenleg Vajdaság 12 kikötője közül 8 nemzetközi. A kikötök jó összeköttetésben 
állnak a közúti és vasúti csomópontokkal, de mégsem épültek melléjük logisztikai központok. (Nagy 2007. 355.)

Vajdaság nem müködik polgári közforgalmú repülötér. Legközelebb Belgrádban érhető el repülőtéri szolgáltatás, viszont létezik 13 kisebb helyi füves sportreptér vagy csak leszállóhely minősítésű létesítmény. Ezek azonban csupán kis (1-3 személyes) könnyü gépek fogadására alkalmasak. Fejlesztés szempontjából a zombori vagy a verseci katonai reptér jöhetne szóba, de polgári repülőtérré alakításukhoz egyelőre gazdasági feltételek és a politikai akarat is hiányzik.

A kombinált áruszállításhoz (melynek, mint egy komplex rendszernek részese a közút, vasút, vízi- és légiközlekedés) a régióban (Vajdaság) a feltételrendszerek adottak, de az infrastruktúra kiépítettségének szintje nem megfelelö, mert jelentösebb nemzetközi logisztikai központok nem épültek, a kisebbek pedig kényszerböl kizárólag csak egy, vagy esetenként két szállítási módot alkalmaznak.

\subsection{Feltételek összefoglalása}

Az időalapú verseny ma már a legfontosabb gazdasági tényezővé vált. Az autópályák regionális hatásukat csak akkor fejtik ki, ha a velük szembeni igényekből fakadó feltétrendszernek eleget tesznek. Megfelelő feltételek teljesítése elősegíti az áruk, a szolgáltatások és a munkaerő mobilitását. Ezek a feltételek nem teljesülnek, akkor az autópályák kihasználtsága alacsony, gazdasági hatásuk gyenge. A problémára irányuló vizsgálat eredményeit a 6. táblázat összesíti.

\section{Táblázat. A Dél-Dunántúl M6-os és Vajdaság 10-es korridort alkotó autópályájának regionális hatásához nélkülözhetetlen feltételrendszer teljesülése}

\begin{tabular}{|c|l|}
\hline $\begin{array}{c}\text { Feltétel } \\
\mathbf{1} . \\
\text { Határtól-határig }\end{array}$ & $\begin{array}{l}\text { Vajdaság E-75-ös (X. korridor) } \\
\text { Korégíti - mert Vajdaságot összeköti Magyarországgal, } \\
\text { Horvátországgal, és ha kiépül, akkor Bulgáriával és Macedóniával. }\end{array}$ \\
\hline $\begin{array}{c}\text { Prosperáló } \\
\text { gazdasági háttár }\end{array}$ & $\begin{array}{l}\text { Nem elégíti ki - mert Vajdaság gazdasági fejlettsége a Szerbia átlaga } \\
\text { alatti, csökken a GDP, a kiviteli ráta, az átlagfizetések, stb. Közben a } \\
\text { munkanélküliség 20\% feletti. }\end{array}$ \\
\hline $\begin{array}{c}\text { 3. } \\
\text { Használatarányos } \\
\text { díjbeszedés }\end{array}$ & $\begin{array}{l}\text { Kielégíti - mert használatarányos díjazás mellett lehet közlekedni, } \\
\text { közben az európai viszonylatban is egyik legolcsóbb autópálya } \\
\text { használati díj fejében lehet a Vajdaságban közlekedni. }\end{array}$ \\
\hline $\begin{array}{c}\text { 4. } \\
\text { Multimodális } \\
\text { szállítás }\end{array}$ & $\begin{array}{l}\text { Részben elégíti ki - mert földrajzi adottságok kedveznek, de a vasút és } \\
\text { a folyami hajózás fejlesztésének elmaradása miatt az intermodális } \\
\text { szállítás feltételeinek teljesítése csak fejlesztési tervek szintjén jelenik } \\
\text { meg. }\end{array}$ \\
\hline
\end{tabular}

Forrás: szerző saját szerkesztése 
Vajdaságban a 10-es autópálya kiépítése az egyik legjelentősebb beruházás. Az autópálya több országot köt össze. Legfontosabb célja, hogy a teherforgalmat biztosítsa a még mindig nem elég fejlett balkáni országok és Európa között. A vizsgálatban megfogalmazott feltételrendszert csak részben elégíti ki, aminek okait a balkáni háborúk utáni szerkezetváltás és fejlesztési programok hiányában kell keresni. A gyenge gazdasági tényezőket akkor lehetne erősíteni, ha Vajdaság vonzóvá válna a befektetők részére azzal, hogy Európa bármely pontjáról egy nap alatt megközelíthető. Az autópálya a helyi gazdaságot akkor tudja támogatni, ha az a gazdaság szerves részévé válik.

\section{A 10-es korridor Vajdaság településeire gyakorolt hatása}

Vajdaság számára fontos tényezővé válhat a 10-es folyosó, mert az elérési idők csökkenése magában rejti a fejlődési potenciált: az autópálya hatására az adott térség közelebb kerül az ország és Európa gazdasági centrumaihoz. (Ohnsorge-Szabó 2006) Vajdaság öt 50 ezer népesség feletti várossal rendelkezik, de erös gazdasági és társadalmi potenciállal csak Újvidék (a tartomány székhelye) büszkélkedhet. Megállapítható, hogy az autópálya a tartomány székhelyének a gyors elérhetőségét segíti. (2. ás 3. ábra)

\section{2. Ábra. A tartomány székhelyének megközelíthetősége gépjárművel (30 perces bontásban)}

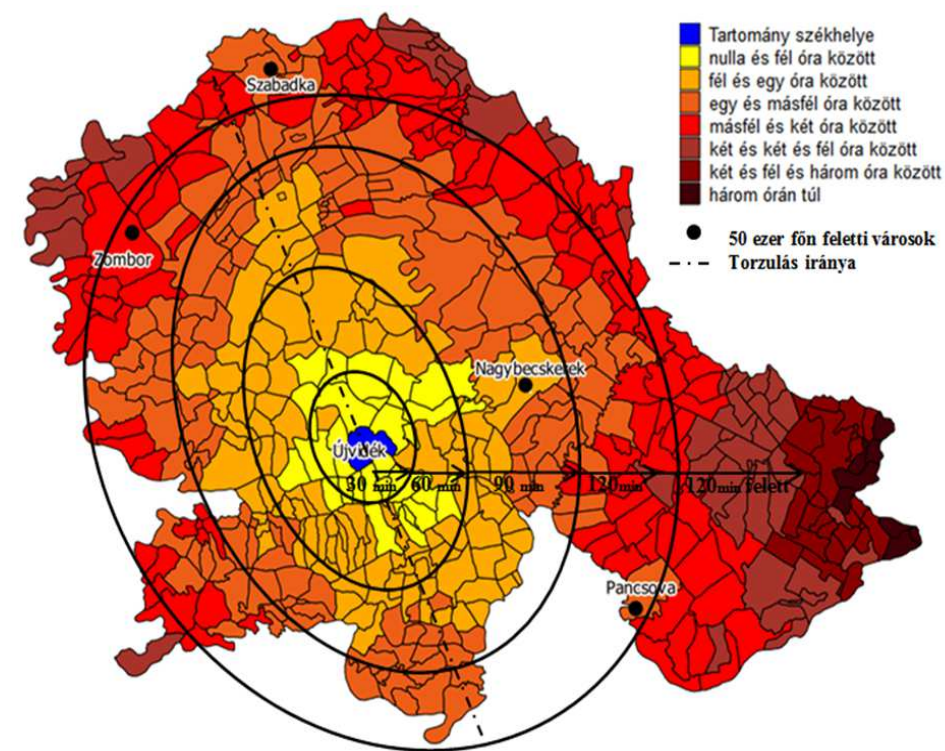

Forrás: szerző saját szerkesztése, a google útvonaltervező segítségével a világhálóról 2013.04.20-22. közötti időszakban elérhető adatok alapján 
Az autópálya igénybevételével jelentkező időbeli előny látványosan a tartomány északi és dél-keleti településeinél (30 perc feletti előny) jelentkezik. Ezzel szemben a tartomány középső területeinél az alsóbb rendű utakat használják a székhely eléréséhez.

\section{3. Ábra. Vajdaságban a 10-es korridor autópálya igénybevételével keletkező időbeli előny a tartományi székhely elérhetőségében (percben)}

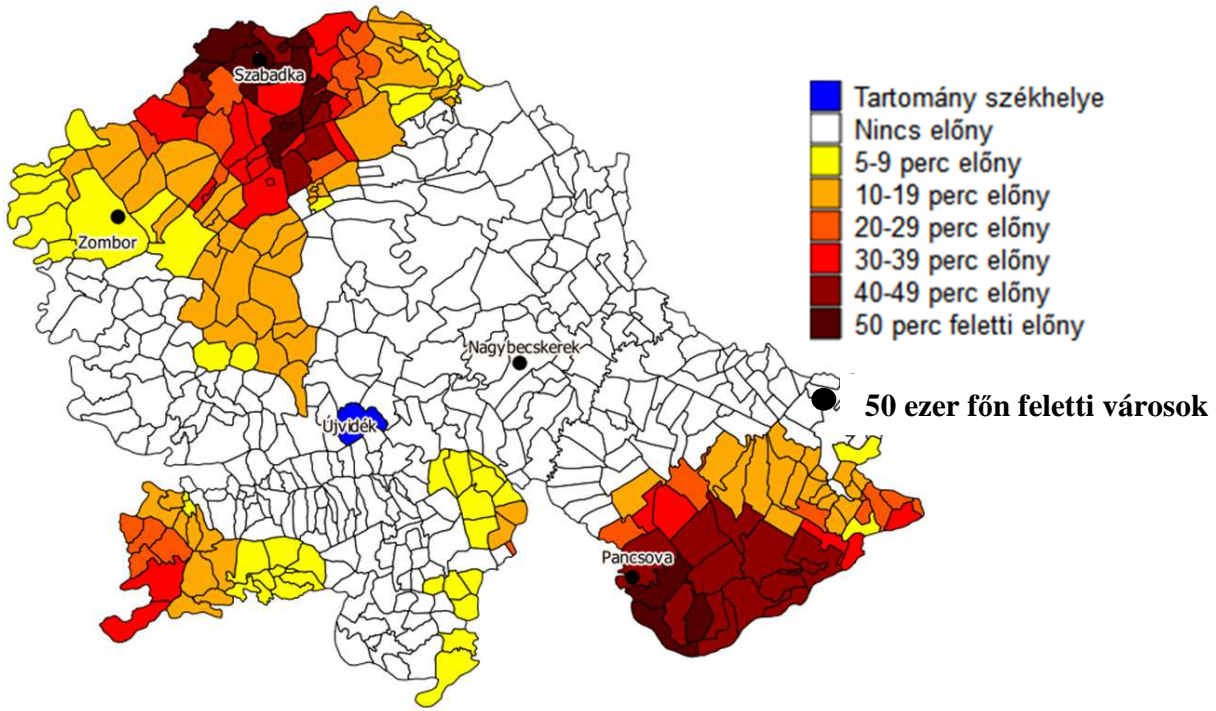

Forrás: szerző saját szerkesztése, a google útvonaltervező segítségével a világhálóról 2013.04.20-22. közötti időszakban elérhető adatok alapján

Szerbia és Vajdaság számára fontos a tranzit áruforgalom nagysága, mert a keleti országok termékei Szerbián keresztül érkeznek és jutnak el nyugatra. A Szerbián áthaladó török tranzit áruforgalom éves szinten 1,74 millió tonnával növekszik. Viszont a vajdasági kkv-ék elsősorban a belső piacra termelnek és a belső piac „elmaradott” feltételrendszereinek próbálnak megfelelni, a külső piacokra jellemző kemény versenyhelyzetet a vállalatok kerülik. Bár a tartomány Szerbia kivitelének 1/3-át adja, ennek ellenére a külkereskedelmi mérleg még mindig 3 milliárd dollár deficittel rendelkezik. A külkereskedelmi mérleg állása rontja Vajdaság versenyképességét a világpiacon (7. táblázat)

\section{Táblázat. Vajdaság külkereskedelmi mérlege}

\begin{tabular}{|l|c|c|}
\hline Indikátor & $\mathbf{2 0 0 7}$ & $\mathbf{2 0 0 8}$ \\
\hline Vajdaság részesedése Szerbia kiviteléből (\%) & 32,2 & 32,5 \\
\hline Vajdaság részesedése Szerbia behozatalából (\%) & 27,1 & 28,7 \\
\hline Külkereskedelmi mérleg (milliárd USD) & $-2188,2$ & $-3029,2$ \\
\hline
\end{tabular}

Forrás: saját szerkesztés a Szerb Statisztikai Hivatal 2010-es éves beszámolója alapján 
Vajdaság és Szerbia számára az autópálya akkor tud gazdasági hasznot hozni, ha nem csak az átmenö forgalom áramlik át területein, hanem új gyárak, logisztika központok, ipari parkok és munkahelyek is létesülnek. Az állam a 17 milliárd dollár külföldi befektetésnek az egyhatodát a 10-es folyosó menti nagyobb központokba irányította azáltal, hogy ott új munkahelyek nyitását támogatta, az állami földeket kedvezményesen adta bérbe, a külföldi befektetök bizonyos járulékok alól menteséget kaptak. A leglátványosabb külföldi befektetésnek a FIAT autógyár kragujevaci részleg megnyitása tekinthető, mert 1.600 mil. euró külföldi tőkebefektetés mellett 2.500 új munkahely létesült. Vajdaság újraiparosodási folyamatában az autópálya közelsége egyértelmű szerepet játszott, mert közelében (Szabadka, Újvidék, Ruma és Ingyia) 21 új külföldi vállalkozó több mint 240 millió eurót fektetett be és ezzel közel 8.000 új munkahely jött létre. (4. ábra).

\section{4. Ábra. A 10-es folyosó vajdasági szakaszai mentén lévő külföldi befektetések (befektetett összeg millió euróban és új munkahelyek száma)}

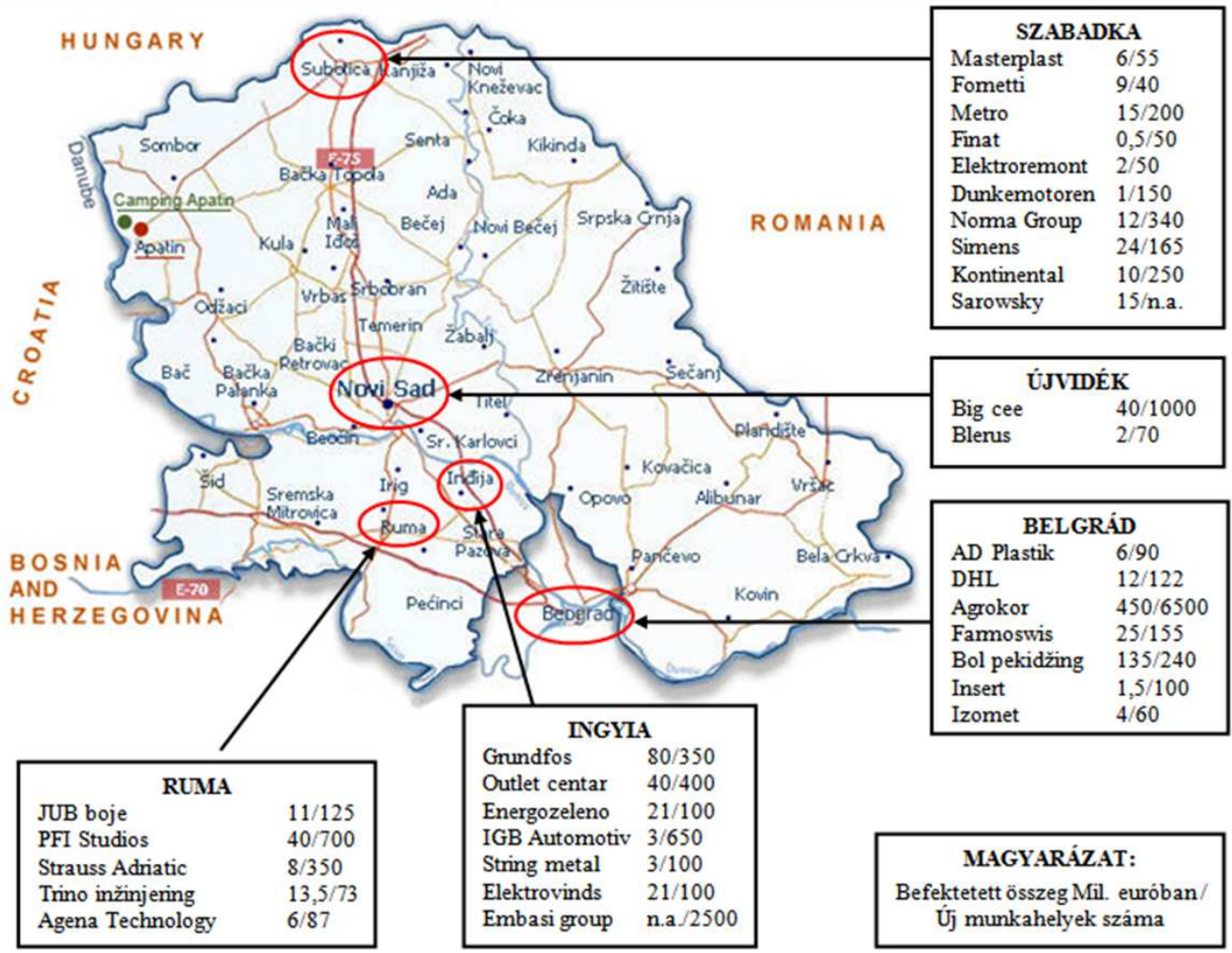

Forrás: szerző saját szerkesztése a Marija Petrović M., Savic K. (2012): „Corridor 10 the importance of the Corridor 10 of economic development of Serbia” tanulmány adatai alapján

\section{ÖSSZEFOGLALÓ}

Az autópálya építését társadalmi elvárások hívták életre. Vajdaság és Szerbia számára a 10-es folyosó az „Európába vezető utat” szimbolizálja. Az ország integrációs folyamatai oly 
mértékben haladnak, mint az országot átszelő 10-es folyosó kiépítése. Ebből a szempontból Vajdaság szerencsés helyzetben van, mert 2012-ben átadta a forgalomnak az első autópályáját.

A pénzügyi tervekből érzékelhető, hogy a 10-es folyosó költségszámítása irreális, a bevételei pedig túlzottak. Megtérülésének kilátásai nem kedvezőek nem csak a magas beruházási költségek, hanem a gyenge forgalom miatt is.

Az autópályák csak akkor tudnak kedvező regionális hatást kifejteni, ha a négy alapfeltételt kielégítik. Azonban a 10-es autópálya esetében az összes feltétel nem teljesült, ebből fakad a gyenge hatás. A tervezéskor elvárt effektust nem tudja teljesíteni.

A gazdasági vizsgálódásnál szembe tủnt, hogy Vajdaságban az autópálya mentén lévő kistérségek jobb gazdasági és társadalmi mutatókkal rendelkeznek. Ez ipartelepítési hatáson keresztül érzékelhető, mert a tartomány autópályájának közelében 21 külföldi vállalat létesült, melyek több mint 240 millió eurót fektettek be és ebből 8000 új munkahely létesült.

Összességben elmondható, hogy a régió autópályájának hatása elsősorban abban mutatkozik meg, hogy segíti a tartomány elérhetőségét, a nagy vállalatok telephely választását, a kisvállalkozók üzleti pozíciójának megerősödését és a helyi lakosság mozgássugarának kiszélesítését.

\section{FELHASZNÁLT IRODALOM}

Cvetanović A. (2008). Koridor 10, Ministarstvo za Infrastrukturu, Beograd. (esettanulmány)

Djordjević S. (2010). Obustava tendera za Koridor 10. RTS (Rádió Televízió Szerbia), megjelent: 2010.02.22., cikk letölthetö:

http://www.rts.rs/page/stories/sr/story/13/ekonomija/521791/obustavatenderazakori

Európai Uniós Hírlevél: A Transz-Európai Közlekedési Hálózat és az országos jelentőségü logisztikai központok. Szerk. EUDESK munkatársai, letölthetö:

http://www.mkb.hu/dl/media/group_463afc792a1fd/group_468a0a6cc1c99/group_468b a652ac6c2/item_432.pdf

Koridor $10 \mathrm{Kft}$., hivatalos honlapja: http://www.koridor10.rs/

Kovács Á. (2011): Vajdaság újraiparosodása az elmúlt tíz évben (Mit eredményezett a privatizáció a régióban, és merre tovább?). Pécsi Tudományegyetem Közgazdaságtudományi Kar Regionális Politika és Gazdaságtan Doktori Iskola Évkönyve, Pécs.

Kovács Á. (2011). X. Pán- (Transzeurópai) autópálya és a vízi közlekedés találkozási pontjai Vajdaságban. Magyar Regionális Tudományi Társaság IX. Vándorgyülés, Révkomárom 2011.11.25. (előadás anyag), letölthető: http://www.mrtt.hu/vandorgyulesek/2011/program.pdf

Majdin Z. (2010). Igranka bez prestanka. Vreme heti lap, megjelent: 2010.04.15., cikk letölthetö: http://www.vreme.com/cms/view.php?id=926055

Marija Petrović M., Savic K. (2012). Corridor 10 the importance of the Corridor 10 of economic development of Serbian. 3rd International Scientific and Professional 
Conference Corridor 10 a sustainable way of integrations, R\&D Institute "Kirilo Savić" a.d. Belgrade, pp. 124-137.

Michael Wegener Spiekermann \& Wegener Urban Regional Research (1999). Overview of land-use transport models. Institut für Raumplanung Fakultät Raumplanung, Universität Dortmund. Dortmund.

Nagy, I. (2007). Vajdaság. Kárpát-medence régiói. Szerk.: Horváth Gyula. MTA Regionális Kutatások Központja, Dialóg Campus.

Németh N. (2005): Az autópálya-hálózat térszerkezet alakító hatásai - Magyarország esete. A hely és a fej. Munkapiac és regionalitás Magyarországon. Szerk.: Fazekas K. MTA Közgazdaságtudományi Intézet. Budapest. pp. 139-179.

Németh, N. (2008). Fejlödési tengelyek az új hazai térszerkezetben - Az autópálya-hálózat szerepe a regionális tagoltságban. PhD-értekezés. Eötvös Loránd Tudományegyetem Természettudományi Kar Regionális Tudományi Tanszék, Budapest-Fonyód.

Ohnsorge-Szabó L. (2006): Közlekedési infrastruktúra és jólét Kelet-Magyarországon. Statisztikai Szemle. 84/3. pp. 249-270.

Szerb Statisztikai Hivatal (2010). Országos Statisztikai Évkönyv, Szerb Statisztikai Hivatal, Belgrád. 